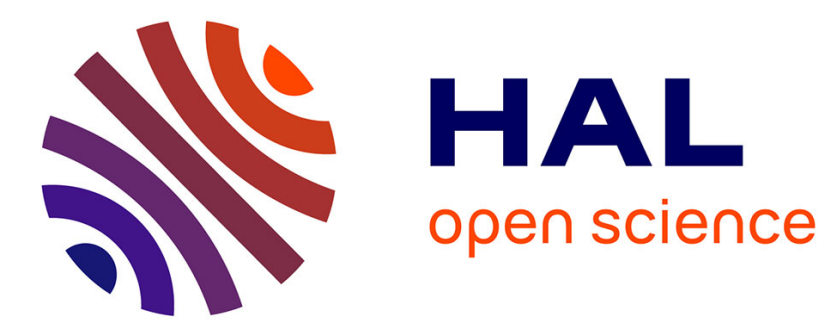

\title{
Lys-gamma3-MSH: A Global Regulator of Hormone Sensitive Lipase Activity?
}

Katrina A Bicknell, Stephen C Harmer, Stephanie Yiangson, Wendy Lockwood, Andrew B Bicknell

\section{> To cite this version:}

Katrina A Bicknell, Stephen C Harmer, Stephanie Yiangson, Wendy Lockwood, Andrew B Bicknell. Lys-gamma3-MSH: A Global Regulator of Hormone Sensitive Lipase Activity?. Molecular and Cellular Endocrinology, 2009, 300 (1-2), pp.71. 10.1016/j.mce.2008.09.032 . hal-00532087

\section{HAL Id: hal-00532087 https://hal.science/hal-00532087}

Submitted on 4 Nov 2010

HAL is a multi-disciplinary open access archive for the deposit and dissemination of scientific research documents, whether they are published or not. The documents may come from teaching and research institutions in France or abroad, or from public or private research centers.
L'archive ouverte pluridisciplinaire HAL, est destinée au dépôt et à la diffusion de documents scientifiques de niveau recherche, publiés ou non, émanant des établissements d'enseignement et de recherche français ou étrangers, des laboratoires publics ou privés. 


\section{Accepted Manuscript}

Title: Lys-gamma3-MSH: A Global Regulator of Hormone Sensitive Lipase Activity?

Authors: Katrina A Bicknell, Stephen C Harmer, Stephanie Yiangson, Wendy Lockwood, Andrew B Bicknell

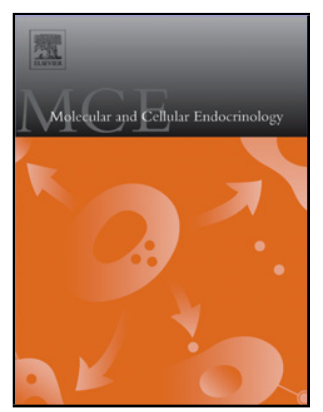

PII:

S0303-7207(08)00428-0

DOI: doi:10.1016/j.mce.2008.09.032

Reference: MCE 7000

To appear in: $\quad$ Molecular and Cellular Endocrinology

Received date: $\quad 15-8-2008$

Revised date: 23-9-2008

Accepted date: $\quad$ 23-9-2008

Please cite this article as: Bicknell, K.A., Harmer, S.C., Yiangson, S., Lockwood, W., Bicknell, A.B., Lys-gamma3-MSH: A Global Regulator of Hormone Sensitive Lipase Activity?, Molecular and Cellular Endocrinology (2008), doi:10.1016/j.mce.2008.09.032

This is a PDF file of an unedited manuscript that has been accepted for publication. As a service to our customers we are providing this early version of the manuscript. The manuscript will undergo copyediting, typesetting, and review of the resulting proof before it is published in its final form. Please note that during the production process errors may be discovered which could affect the content, and all legal disclaimers that apply to the journal pertain. 
Lys-gamma3-MSH: A Global Regulator of Hormone Sensitive Lipase Activity?

Katrina A Bicknell ${ }^{\#}$, Stephen C Harmer, Stephanie Yiangson, Wendy Lockwood ${ }^{\#}$ and Andrew B Bicknell*

School of Biological Sciences and "School of Pharmacy, The University of Reading, Whiteknights, PO Box 228, Reading, Berkshire, RG6 6AJ UK.

Tel: +44 (0)1183787050

Fax: +44 (0)1189310180

*Corresponding author

Email: A.B.Bicknell@ rdg.ac.uk

Key Words: Adrenal, Adipocyte, gamma-MSH, Heart, POMC, Steroidogenesis 


\begin{abstract}
Gamma-melanocyte stimulating hormone $(\gamma-\mathrm{MSH})$ is a peptide derived from the ACTH precursor, pro-opiomelanocortin (POMC), and belongs to a family of peptides called the melanocortins that also comprises alpha and beta MSH. Although conserved in tetrapods, the biological role of $\gamma$-MSH remains largely undefined. It has been demonstrated previously that $\gamma$-MSH is involved in the regulating the activity of hormone sensitive lipase (HSL) activity in the adrenal and more recently, in the adipocyte. It has been shown also to have effects on the cardiovascular and renal systems.

This short review will provide a brief overview of the role of $\gamma$-MSH in the adrenal and the more recent report that it can also regulate HSL function in the adipocyte. We also present some preliminary data purporting a direct role for Lys- $\gamma 3-\mathrm{MSH}$ in the regulation of HSL phosphorylation in the heart. Taken together these data suggest that $\gamma$-MSH peptides might play a more widespread role in lipid and cholesterol utilization.
\end{abstract}




\section{Historical perspectives/Introduction}

MSH biology began in the 1950s with the purification and characterization of $\alpha$ and $\beta$ MSH. These two peptides, that both have the ability to induce changes of skin color in amphibia and fish, contain a core sequence of Glu-His-Phe-Arg-Trp that is essential for the biological activities of these peptides. The cloning of the gene for POMC in 1979 (Nakanishi et al., 1979) revealed, not only that these two MSH peptides were derived from the same precursor, but that the POMC sequence also encoded a third MSH-like peptide. This peptide was named gamma-MSH $(\gamma-\mathrm{MSH})$ and is located in the amino terminal of the molecule known as the $16 \mathrm{KDa}$ fragment (subsequently also known as pro$\gamma$-MSH). It is flanked by classical dibasic residue processing sites and contains a slightly modified MSH core sequence, Gly-His-Phe-Arg-Trp, where the Glu is substituted for a Gly. Based on the location of these processing sites, the authors predicted three possible processed products (Figure 1) that have persisted in the literature: $\gamma_{1}$ MSH is 11 residues long and represents a fully processed amidated peptide, $\gamma_{2} \mathrm{MSH}$ is the same peptide but without the amidation, while $\gamma_{3}$ MSH contains the sequence up to the next dibasic site at the N-terminal of the joining peptide.

Cloning and sequencing of the POMC gene from other species has revealed the absence of the $\gamma$ MSH sequence in some species. Although present in all tetrapods, among fish the $\gamma$ MSH sequence is absent from the most recently evolved ray-finned fish - the euteleosts such as carp, salmon and trout (For a review see Dores and Lecaude, 2005). Interestingly, $\gamma \mathrm{MSH}$ is present in the evolutionary older cartilaginous fish and in the younger lobefinned fish, leading to the hypothesis that the euteleosts have actually lost the $\gamma \mathrm{MSH}$ sequence (Dores and Lecaude, 2005). 
In mammals the sequence of $\gamma_{1} \mathrm{MSH}$ is highly conserved, although the C-terminal sequence of $\gamma_{3} \mathrm{MSH}$ is not. This variation suggests that this region might not be important for biological action. Another significant variation occurs in the rat, where the Arg-Arg processing site needed to create $\gamma_{1} \mathrm{MSH}$ is changed to Pro-Arg, suggesting that this peptide is probably absent in this species (Jackson et al., 1983; Pedersen et al., 1982).

Although the cloning of the POMC gene suggested the existence of these new MSH peptides, it was not until 1981 that they were first purified from bovine brain and pituitary. Full characterization of these peptides convincingly showed the existence of $\gamma_{1}$ and $\gamma_{3} \mathrm{MSH}$ (Bohlen et al, 1981; Browne et al., 1981), although there was no evidence for the existence of $\gamma_{2} \mathrm{MSH}$.

The most surprising observation from the purification studies was that both $\gamma_{1}$ and $\gamma_{3}$ carry an additional lysine at the $\mathrm{N}$-terminus. The fact that this was not predicted from the gene sequence was a consequence of the assumption that cleavage occurs at the Cterminal side of the dibasic pair, which is not actually the case - cleavage occurs at the Cterminal side of the arginine residue (Zhou et al., 1993). The majority of POMC peptides are flanked by Lys-Arg (the most efficient combination for cleavage by the prohormone convertase enzymes) and thus cleavage occurs at the C-terminal side of the dibasic pair. However $\gamma$-MSH is flanked at its N-terminal with an uncommon Arg-Lys site; consequently cleavage occurs after the lysine and not at the C-terminal side of the dibasic pair.

The fact that this additional Lys residue appears to be essential for full biological activity, at least in the adrenal (Pedersen and Brownie, 1983), makes it not unreasonable to 
hypothesize that the importance of this lysine has placed sufficient evolutionary pressure on the system to retain the Arg-Lys cleavage site.

Despite clear experimental evidence showing the presence and importance of the lysine at the N-terminus of the $\gamma$-MSH peptides, they are not readily available commercially. No doubt as a result of this, most studies in the literature have used $\gamma$-MSH peptides that lack this critical residue.

\section{The biological role of gamma-MSH}

Unlike $\alpha-\mathrm{MSH}$ and ACTH, the $\gamma$-MSH peptides have not been intensively investigated. The first reports for a role for these peptides appeared in the early 1980s (for a review see Harmer and Bicknell, 2005) when it was demonstrated that Lys- $\gamma 3-\mathrm{MSH}$ and pro- $\gamma-\mathrm{MSH}$, although not directly steroidogenic, have the ability both in vitro and in vivo to potentiate the steroidogenic response of the rat adrenal to ACTH (Figure 2) (Pedersen \& Brownie 1980, Pedersen et al. 1980, Al-Dujaili et al. 1981). This effect appears to correlate with the ability of both peptides to increase the activity of the enzyme Hormone Sensitive Lipase (HSL) (Pedersen et al. 1980). HSL was first characterized in adipose tissue (Trzeciak et al., 1984) and is critical for the stimulated breakdown of triacylglycerol ( $\mathrm{Li}$ et al., 2002), but also has the ability to hydrolyze cholesterol esters. Since the majority of cholesterol in the cell exists in an esterified form, the increase in HSL activity ultimately results in an increase in the amount of free cholesterol to feed into the steroidogenic pathway (Pedersen and Brownie, 1987).

Characterization of the activity of $\gamma$-MSH by Pedersen and Brownie revealed that deletion of the amino terminal lysine of Lys- $\gamma_{3}-\mathrm{MSH}$, to generate $\gamma_{3}-\mathrm{MSH}$, results in a reduction 
of adrenotropic potency to $2 \%$, in comparison to synthetic Lys- $\gamma_{3}-\mathrm{MSH}$. It was shown also that residues (1-11) contain almost all the information needed for bioactivity, while the C-terminal region (12-24) has limited influence on the bioactivity of Lys- $\gamma_{3}-\mathrm{MSH}$ (Pedersen and Brownie, 1983). This latter observation might be expected considering the lack of conservation between species of the sequence in this region.

In the same study, Pedersen and Brownie used radio-ligand binding to investigate the existence of a $\gamma$-MSH receptor expressed by the adrenal gland. They showed that rat adrenal cortex membrane preparations not only possessed high affinity binding sites for radio-labelled Lys- $\gamma 3$-MSH distinct from those for ACTH (Pedersen \& Brownie, 1983), but that binding was not confined solely to the adrenal. In comparison, higher levels of binding were observed in rat adipose tissue, skeletal muscle and testes membrane preparations and lower levels of binding in rat cardiac muscle, ovary and spleen membrane preparations (Pedersen \& Brownie, 1983).

\section{A role for $\gamma$-MSH in the adipocyte}

The widespread binding of Lys- $\gamma 3-\mathrm{MSH}$ led Pedersen and Brownie to speculate the possible existence of a functional relationship between Lys- $\gamma 3-\mathrm{MSH}$ binding and lipid/cholesterol utilization. It also seems reasonable to hypothesize that Lys- $\gamma 3-\mathrm{MSH}$ may have a widespread role in the regulation of HSL, since it appears to be the key enzyme affected by Lys- $\gamma 3-\mathrm{MSH}$ in the adrenal. Indeed, comparison of the expression pattern of HSL to that of the binding profile of Lys- $\gamma 3-\mathrm{MSH}$ shows HSL expressed in every tissue that shows specific binding of Lys- $\gamma 3-\mathrm{MSH}$. 
To further investigate this hypothesis we looked at the effects of Lys- $\gamma 3$-MSH on the adipocyte, the tissue with the highest specific binding. The melanocortin peptides, ACTH, $\alpha-\mathrm{MSH}$ and $\beta$-lipotrophin (LPH), have long been known to promote lipolysis, to varying degrees, in the adipocytes of various mammalian species (White and Engel, 1958; Ramachandran et al., 1976; Ramachandran and Lee, 1976; Boston, 1999). However, only one study $(\mathrm{Ng}, 1990)$ can be found showing that $\gamma 1-\mathrm{MSH}$, (without the Nterminal lysine), is weakly lipolytic in rabbit adipocytes. Using glycerol release as a measure, Lys- $\gamma 3$-MSH was found to be a potent stimulator of lipolysis (Figure 3) with an apparent $\mathrm{EC}_{50}$ of $3.56 \mathrm{nM}$ (Harmer et al., 2008). In order to investigate the molecular basis for this lipolytic effect we investigated the phosphorylation of HSL at key residues known to affect its activity (Figure 4a). Phosphorylation at Ser 660 and Ser 563 increase the activity of HSL while Ser 565 is basally phosphorylated and believed to prevent the phosphorylation of Ser 563. Immunoblotting showed that Lys- $\gamma 3-\mathrm{MSH}$ could stimulate the phosphorylation of Ser 660 and 563 whilst also reducing the phosphorylation of Ser 565. We extended these studies to look at the phosphorylation of Perilipin A, a molecule that in its un-stimulated state surrounds the lipid droplet protecting it from HSL activity. Upon phosphorylation Perilipin A, moves away from the droplet allowing access to HSL. Lys- $\gamma 3$-MSH was found to phosphorylate Perilipin A (Figure $4 \mathrm{~b}$ ) in a dose dependent manner.

These results show that Lys- $\gamma 3-\mathrm{MSH}$ can activate HSL and Perilipin A resulting in lipolysis, supporting the hypothesis that Lys- $\gamma 3$-MSH may have a wider role in lipid/cholesterol utilization. 


\section{A role for Lys- $\gamma 3-\mathrm{MSH}$ in other tissues?}

With clear evidence for a role for Lys- $\gamma 3-\mathrm{MSH}$ in the regulation of HSL activity in the adrenal and the adipocyte the question arises as to what effect the peptide has on other tissues that both express HSL and also bind it with high affinity. To further investigate this we have recently started to investigate the effects of Lys- $\gamma 3$-MSH on the heart. Various gamma-MSH peptides have been shown to affect the cardiovascular system (Humphreys, 2007) increasing blood pressure and heart rate, although these are believed to be the result of changes in sympathetic outflow from the CNS rather than a direct effect on the heart. However, the heart does express HSL and also binds Lys- $\gamma 3-\mathrm{MSH}$, observations that open up the possibility that Lys- $\gamma 3-\mathrm{MSH}$ may have a direct action on the heart. Since previous studies have demonstrated that HSL is expressed in rat cardiac myocytes (Small et al., 1989), we have investigated the effect that Lys- $\gamma 3-\mathrm{MSH}$ stimulation has on HSL phosphorylation in cultured primary neonatal rat cardiac myocytes. Treatment of serum-starved cardiac myocytes with Lys- $\gamma 3-\mathrm{MSH}$ resulted in rapid and dose-dependent phosphorylation of HSL (Ser 660) at doses as low as $10 \mathrm{pmol}$ (Figure 5a). In view of the fact that the heart is made up several different cell types (i.e. cardiac myocytes, fibroblasts, endothelial cells and vascular smooth muscle cells), and that non-myocyte cell populations are likely to represent approximately $5 \%$ of the cells present in primary cultures, we sought to demonstrate that HSL was phosphorylated in cardiac myocytes in response to Lys- $\gamma 3-\mathrm{MSH}$. Immunofluorescence demonstrated coexpression of Ser 660-phosphorylated HSL and the cardiac myocyte marker, sarcomeric tropomyosin, in Lys- $\gamma 3-\mathrm{MSH}$-stimulated cardiac myoctes (Figure 5b). 
These observations of dose-dependent phosphorylation of HSL in response to picomolar doses of Lys- $\gamma 3-\mathrm{MSH}$ in cardiac myocytes, when taken together with the earlier binding study by Pederson and Brownie demonstrating Lys- $\gamma 3-\mathrm{MSH}$ binding in heart tissue, strongly support the existence of a direct role for Lys- $\gamma 3-\mathrm{MSH}$ in the regulation of HSL activity in the heart. However, the functional significance of these observations will require further investigation.

\section{A receptor specific for $\gamma$-MSH?}

The effects of Lys- $\gamma 3-\mathrm{MSH}$ on the adrenal and the ligand binding studies were described before the identification of the melanocortin receptors (MCRs). These receptors were identified in the 1990's and comprise a family of 5 related G-protein coupled receptors, denoted MC1-5R, that have a varied tissue distribution and ligand specificity (Table 1) (For a recent review see Wikberg and Mutulis, 2008). Of the 5 MCRs only the MC3R has been shown to have any significant affinity for $\gamma$-MSH (Gantz et al., 1993), although its role in mediating the effects of $\gamma$-MSH on HSL activity are contradicted by several pieces of evidence. Firstly, the mRNA expression profile of the MC3R is not the same as the binding profile described by Pedersen and Brownie, although expression of the MC3R has been reported in the rat adrenal (Dhillo et al., 2003). Secondly, ACTH is as potent an agonist at the MC3R as $\gamma$-MSH, which does not correlate with the low affinity for the Lys- $\gamma 3$-MSH binding site described reported by Pedersen and Brownie. Thirdly, we have shown previously that SHU9119 (an antagonist at the MC3R and MC4R) is unable, or conversely MTII (an agonist of the MC3 and MC4R) able to mimic the synergistic actions of pro- $\gamma-\mathrm{MSH}$ on ACTH induced steroidogenesis (Harmer and Bicknell, 2004). 
Finally, our recent study in adipocytes showed that HS024 (an antagonist at the MC1, 3, 4 and 5 receptors) was incapable of blocking the lipolysis stimulated by Lys- $\gamma 3-\mathrm{MSH}$ (Harmer et al., 2008).

These observations are not easy to interpret, but suggest that the pharmacology of the known MCRs is either more complicated than previously thought, or that there might exist another, as yet uncharacterized, melanocortin receptor specific for Lys- $\gamma 3-\mathrm{MSH}$.

\section{Summary}

Gamma-MSH was one of the first peptides to have had its sequence predicted from the DNA sequence of the genes that encodes it. The subsequent purification of the peptide and the identification of the additional $\mathrm{N}$-terminal lysine, serves as a timely reminder that purification of the native molecule is still an important part of the characterization process.

The biological role of $\gamma-\mathrm{MSH}$ is still not fully understood. However, the data from the adrenal, the adipocyte and the heart, lends credible evidence to the idea that it is involved with the global regulation of HSL activity. Whether this holds true in all the other tissues that express HSL and binding sites for $\gamma$-MSH, and as importantly whether it is physiological relevant, remains to be determined and certainly warrants further investigation.

\section{References}


Al-Dujaili, E.A., Hope, J., Estivariz, F.E., Lowry, P.J., Edwards, C.R., 1981 Circulating human pituitary pro-gamma-melanotropin enhances the adrenal response to ACTH. Nature 29, 156-159.

Bicknell, K.A., Coxon, C.H. and Brooks, G., 2004. Forced expression of the cyclin B1CDC2 complex induces proliferation in adult rat cardiomyocytes. Biochem. J. 382, 411416.

Bohlen, P., Esch, F., Shibasaki, T., Baird, A., Ling, N., Guillemin, R., 1981. Isolation and characterization of $\gamma_{1}$-Melanotropin-like peptide from bovine neurointermediate pituitary. FEBS Letters 128, 67-70.

Browne, C.A., Bennett, H.P.J, Solomon, S., 1981. The isolation of characterization of gamma 3-melanotropin from the neurointermediary lobe of the rat pituitary. Biochem. Biophys. Res. Commun. 100, 336-343.

Boston, B.A., 1999. The role of melanocortins in adipocyte function. Annals of the New York Academy of Sciences 885, 75-84.

Dhillo, W.S., Small, C.J., Gardiner, J.V., Bewick, G.A., Whitworth, E.J., Jethwa, P.H., Seal, L.J., Ghatei, M.A., Hinson, J.P., Bloom, S.R., 2003. Agouti-related protein has an inhibitory paracrine role in the rat adrenal gland. Biochem. Biophys. Res. Commun. 301, 102-107.

Dores, R.M., and Lecaude, S., 2005. Trends in the evolution of the proopiomelanocortin gene, Gen. Comp. Endocrinol. 142, 193-205.

Gantz, I., Konda, Y., Tashiro, T., Shimoto, Y., Miwa, H., Munzert, G., Watson, S.J., DelValle, J., Yamada, T., 1993. Molecular cloning of a novel melanocortin receptor. J Biol. Chem. 268, 8246-8250.

Jackson, S., Salacinski, P., Hope, J., Lowry, P.J., 1983. An investigation of N-terminal pro-opiocortin peptides in the rat pituitary. Peptides 4, 431-438.

Li, H., Brochu, M., Wang, S.P., Rochdi, L., Cote, M., Mitchell, G., Gallo-Payet, N., 2002. Hormone-sensitive lipase deficiency in mice causes lipid storage in the adrenal cortex and impaired corticosterone response to corticotropin stimulation. Endocrinology $143,3333-3340$.

Harmer, S.C., Bicknell, A.B., 2004. The role of the melanocortin 3 receptor in mediating the effects of gamma-MSH peptides on the adrenal. Endo. Res. 30, 629-35.

Harmer, S.C., Bicknell, A.B., 2005. Role of gamma-MSH peptides in the regulation of adrenal steroidogenesis. Peptides 26, 1944-1951. 
Harmer, S.C., Pepper, D.J., Cooke, K., Bennett, H.P.J., Bicknell, A.B., 2008. Evidence of a possible role for Lys- $\gamma 3-\mathrm{MSH}$ in the regulation of adipocyte function. J. Endocrinology 196, 149-158.

Humphreys, M.H., 2007. Cardiovascular and renal actions of melanocyte-stimulating hormone peptides. Curr. Opin. Nephro. Hypertens. 16, 32-38.

MacNeil, D.J., Howard, A.D., Guan, X., Fong, T.M., Nargund, R.P., Bednarek, M.A., Goulet, M.T., Weinberg, D.H., Strack, A.M., Marsh, D.J., Chen, H.Y., Shen, C.P., Chen, A.S., Rosenblum, C.I., MacNeil, T., Tota, M., MacIntyre, E.D., Van der Ploeg, L.H., 2002.The role of melanocortins in body weight regulation: opportunities for the treatment of obesity. Eur. J. Pharmacol. 450, 93-109.

Nakanishi, S., Inoue, A., Kita, T., Nakamura, M., Chang, A.C., Cohen, S.N., Numa, S., 1979. Nucleotide sequence of cloned cDNA for bovine corticotropin-beta-lipotropin precursor. Nature 278, 424-427.

Ng, T.B., 1990. Studies on hormonal regulation of lipolysis and lipogenesis in fat cells of various mammalian species. Comp. Biochem. Physiol. B, Comp. Biochem. 97, 441-446.

Pedersen, R.C., Brownie, A.C., 1980. Adrenocortical response to corticotropin is potentiated by part of the amino-terminal region of pro-corticotropin/endorphin. Proc. Natl. Acad. Sci. U. S. A. 77, 2249-2243.

Pedersen, R.C., Brownie, A.C., Ling, N., 1980. Pro-adrenocorticotropin/endorphinderived peptides: coordinate action on adrenal steroidogenesis. Science 208, 1044-1046. Pedersen, R.C., Ling, N., Brownie, A.C., 1982. Immunoreactive gamma-melanotropin in rat pituitary and plasma: a partial characterization. Endocrinology 110, 825-834.

Pedersen, R.C., Brownie, A.C., 1983. Lys- $\gamma_{3}$-Melanotropin binds with high affinity to the rat adrenal cortex. Endocrinology 112, 1279-1287.

Pedersen, R.C., Brownie, A.C., 1987. Gamma 3-melanotropin promotes mitochondrial cholesterol accumulation in the rat adrenal cortex. Mol. Cell. Endocrinol. 50, 149-156.

Ramachandran, J., Farmer, S.W., Liles, S., Li, C.H., 1976. Comparison of the steroidogenic and melanotropic activities of corticotropin, alpha-melanotropin and analogs with their lipolytic activities in rat and rabbit adipocytes. Biochimica et Biophysica Acta 428, 347-354.

Ramachandran, J., Lee, V., 1976. Divergent effects of adrenocorticotropin and melanotropin on isolated rat and rabbit adipocytes. Biochimica et Biophysica Acta 428, $339-346$.

Small, C.A, Garton, A.J., Yeaman, S.J., 1989. The presence and role of hormonesensitive lipase $\mathrm{n}$ heart muscle. Biochem. J. 258, 67-72. 
Trzeciak, W.H., Sonnenborn, U., Balkow, C., Kunau, W.H., 1984. Regulation of steroidogenesis in rat adrenal gland: identification of the bifunctional, hormone-sensitive cholesterol esterase--triacylglycerol lipase enzyme protein and its discrimination from hormone-insensitive lipases. Mol. Cell. Endocrinol. 35, 131-141.

Wikberg, J.E., Mutulis, F., 2008. Targeting melanocortin receptors: an approach to treat weight disorders and sexual dysfunction. Nat. Rev. Drug Discov. 7, 307-323.

White, J.E., Engel, F.L., 1958. Lipolytic action of Corticotropin on rat Adipose Tissue In Vitro. J. Clin. Invest. 37, 1556-1563.

Zhou, A., Bloomquist, B.T., Mains, R.E., 1993. The prohormone convertases PC1 and PC2 mediate distinct endoproteolytic cleavages in a strict temporal order during proopiomelanocortin biosynthetic processing. J. Biol. Chem. 268, 1763-1769.

\section{Acknowledgements}

We are grateful to The Wellcome Trust, Biotechnology and Biological Sciences Research Council and the British Heart Foundation for funding.

\section{Figure Legends}

Figure 1: Sequence comparison of the rat MSH peptides. Three species of MSH were proposed by Nakanishi et al, $1979-\gamma_{1^{-}} \gamma_{2^{-}} \gamma_{3^{-}}$MSH. Purification of both $\gamma_{1}$ and $\gamma_{3}$-MSH from the pituitary clearly show that cleavage occurs after the arginine residue of the ArgLys cleavages site resulting in the retention of the lysine residue at the $\mathrm{N}$-terminal.

Figure 2: Lys- $\gamma_{3}-\mathrm{MSH}$ potentiates the steroidogenic actions of ACTH. Isolated at adrenal cells were packed into two separate columns (control and treated) and continuously perfused as previously described (Harmer and Bicknell, 2004). Pulses of ACTH (1ng/l) (hatched boxes) were given to both columns, while the treated column was also given an increasing dose of purified Lys- $\gamma_{3}-\mathrm{MSH}$. A clear potentiating effect can be seen at doses above $1 \mathrm{pM}$.

Figure 3: Lys- $\gamma_{3}-\mathrm{MSH}$ stimulates lipolysis in 3T3 L1 adipocytes. Cells were cultured as described in Harmer et al., 2008 and were incubated with various doses of purified Lys$\gamma_{3}$-MSH. After $4 \mathrm{hrs}$ incubation, glycerol content of the media was measured using a serial enzymic assay. Results are expressed relative to untreated cells ( \pm SEM) with the curve fitted using GraphPad Prism.

Figure 4a: Lys- $\gamma_{3}-$ MSH stimulates a dose dependent phosphorylation of HSL and Perilipin A at key serine residues in 3T3 L1 adipocytes. Cells were cultured as described 
in Harmer et al., 2008 and were incubated with various doses of purified Lys- $\gamma_{3}-\mathrm{MSH}$. After 20 mins incubation, cells were lysed and the extracts immunoblotted with either total or phospho specific HSL antibodies. Phospho specific bands were scanned by densitometry and are represented as a ratio of total HSL expression $( \pm \mathrm{SEM})$.

4b: Cell lysates were also blotted with a specific Perilipin A antibody. When phopshorylated Perilipin A undergoes a significant shift from 62-67KDa. Bands were scanned and are represented as a the percentage of Perilipin A that migrated at $67 \mathrm{KDa}$ $( \pm$ SEM). In both $4 a$ and $b * p<0.05, * * p<0.01$ compared to untreated control.

Figure 5: Lys- $\gamma_{3}-\mathrm{MSH}$ stimulates a dose dependent phosphorylation of HSL at Ser-660 in primary neonatal rat cardiac myocytes. Cells were isolated from 2 day old Wistar rat ventricles as described previously by Bicknell et al., 2004. Enriched cardiomyocytes (95\% pure) were allowed to adhere overnight before being serum-starved for 48hours. Cultures were then stimulated with various doses of purified Lys- $\gamma_{3}-\mathrm{MSH}$. (A) After 20 mins incubation, cells were lysed and the extracts immunoblotted with phospho-specific Ser660 HSL antibody. (B) To confirm that Lys- $\gamma_{3}-\mathrm{MSH}$ induced activation of Ser-660 phosphorylation in cardiac myocytes and not in contaminating non-myocytes, immunofluorescence was performed as described (Bicknell et al., 2004) using antisarcomeric tropomyosin (red) and anti-phospho-Ser-660 HSL (green) antibodies. Nuclei of cells were stained with DAPI (blue). Cardiac myocytes containing phosphorylated HSL (Ser-660) are indicated with arrowheads. (C) Control cells in which the primary antibody were omitted showing the absence of non-specific staining.

Table 1: Characteristics of the 5 known melanocortin receptors showing binding affinities, expressed as $\mathrm{EC}_{50}(\mathrm{nM})$ values, and tissue distribution as determined by northern and PCR analysis. Data modified from MacNeil et al., 2002. 
$\alpha$-MSH Ac-Ser-Tyr-Ser-Met-Glu-His-Phe-Arg-Trp-Gly-Lys-Pro-Val-NH2

B-MSH Ala-Asp-Gly-Pro-Tyr-Arg-Val-Glu-His-Phe-Arg-Trp-Gly-Asn-Pro-Pro-Lys-Asp

$\gamma-\mathrm{MSH}$

Tyr-Val-Met-Gly-His-Phe-Arg-Trp-Asp-Arg-Phe-NH2

$\gamma-\mathrm{MSH}$

Tyr-Val-Met-Gly-His-Phe-Arg-Trp-Asp-Arg-Phe-Gly

$\gamma-\mathrm{MSH}$

Tyr-Val-Met-Gly-His-Phe-Arg-Trp-Asp-Arg-Phe-Gly-Pro-Arg-Asn-Ser-Ser-Ser-Ala-Gly-Gly-Ser-Ala-Gin

Lys- $\beta-\mathrm{MSH}$

Lys-Tyr-Val-Met-Gly-His-Phe-Arg-Trp-Asp-Arg-Phe-Gly-Pro-Arg-Asn-Ser-Ser-Ser-Ala-Gly-Gly-Ser-Ala-Gin 


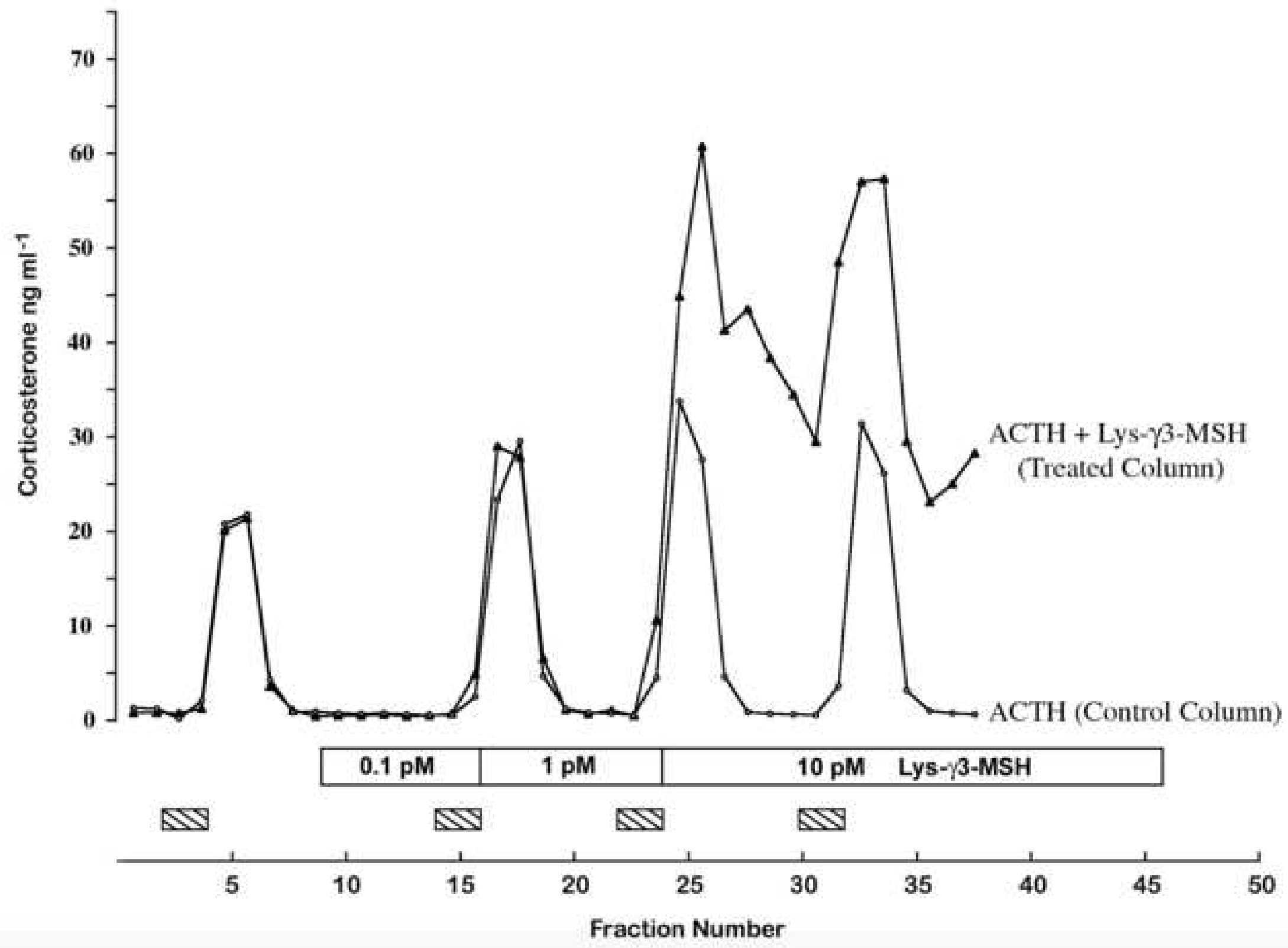

rage 16 or 20 


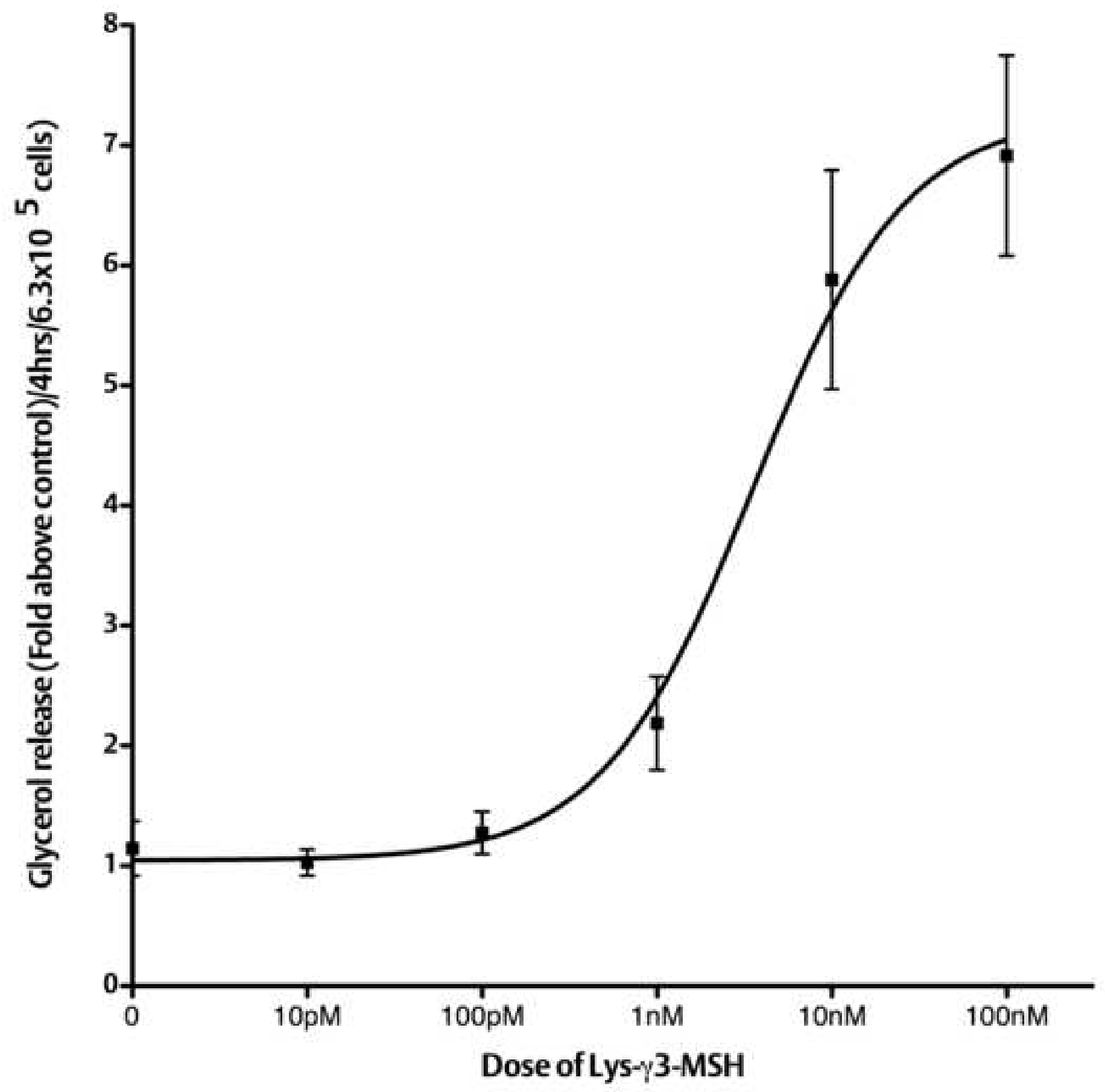


A

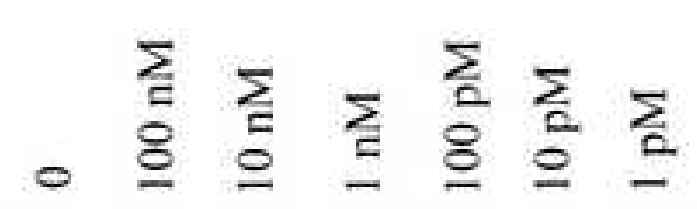
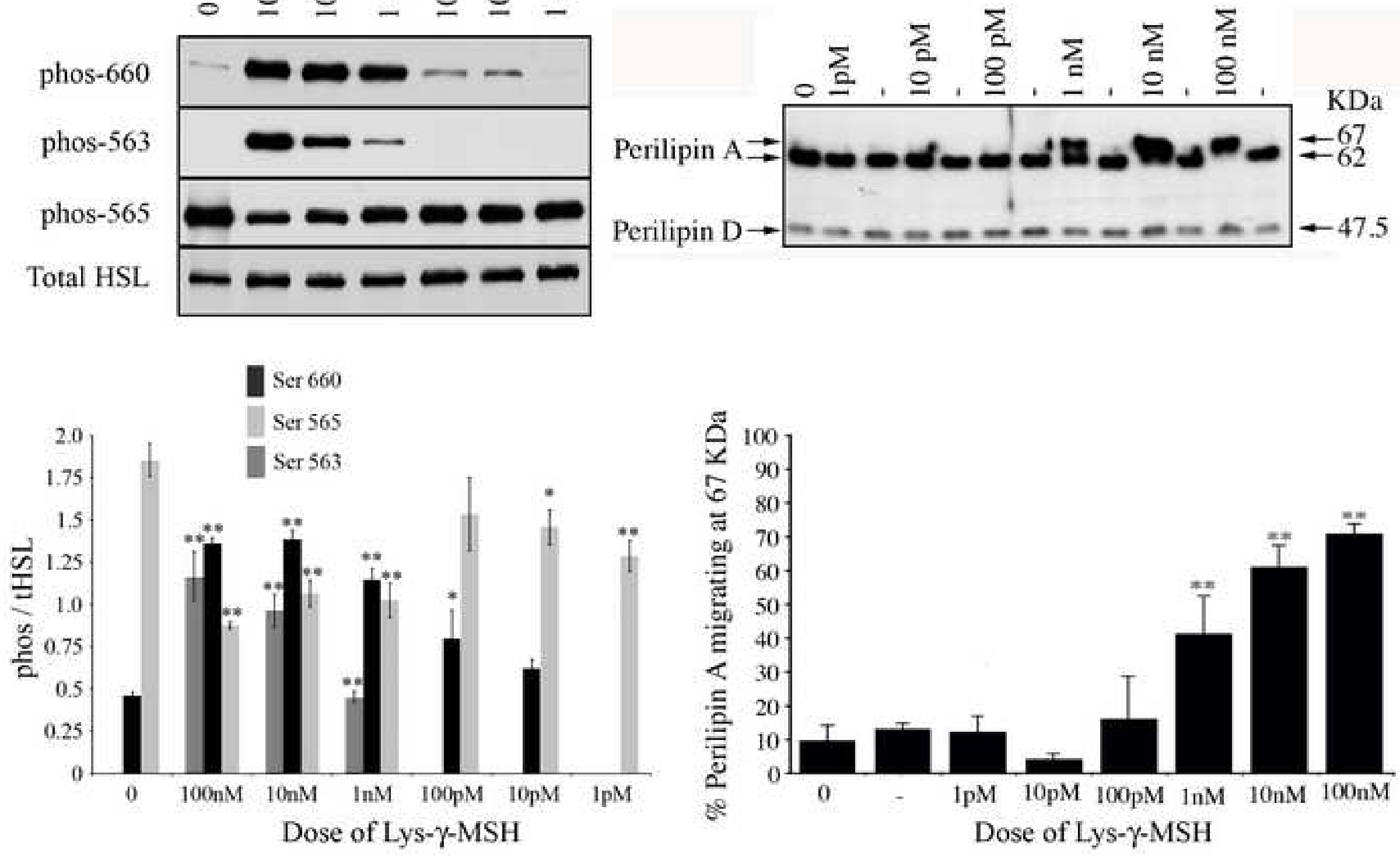
A

Dose of Lys- $\gamma$ 3-MSH

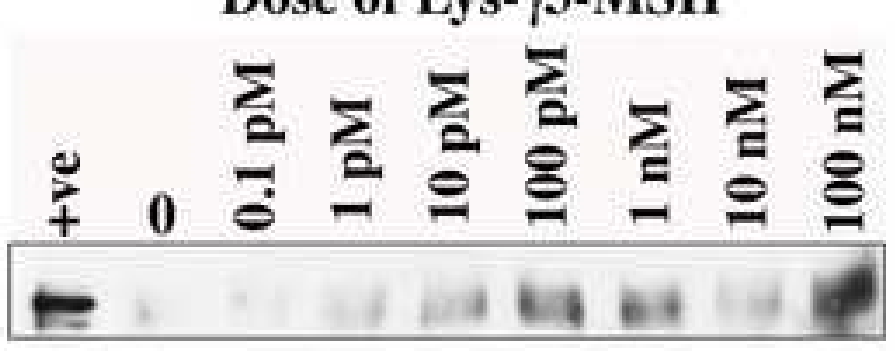

DAPI

Phos HSL Ser 660
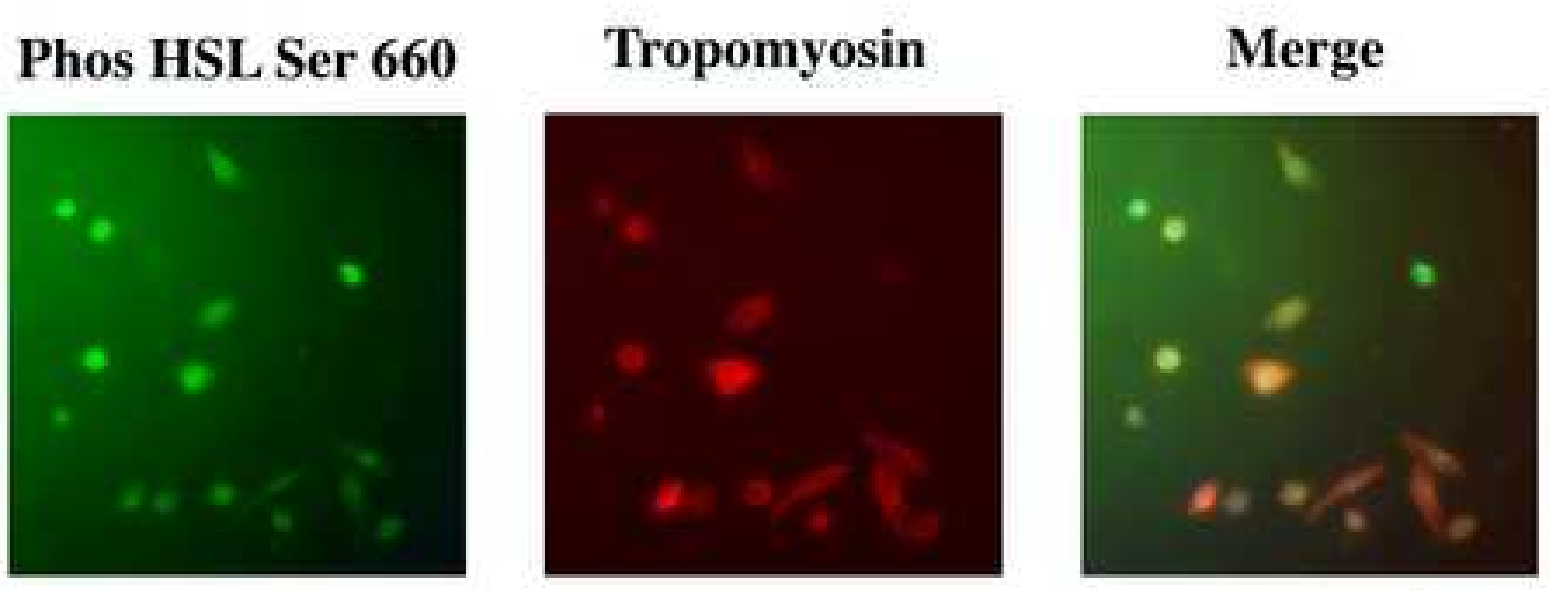

$50 \mu \mathrm{M}$

B
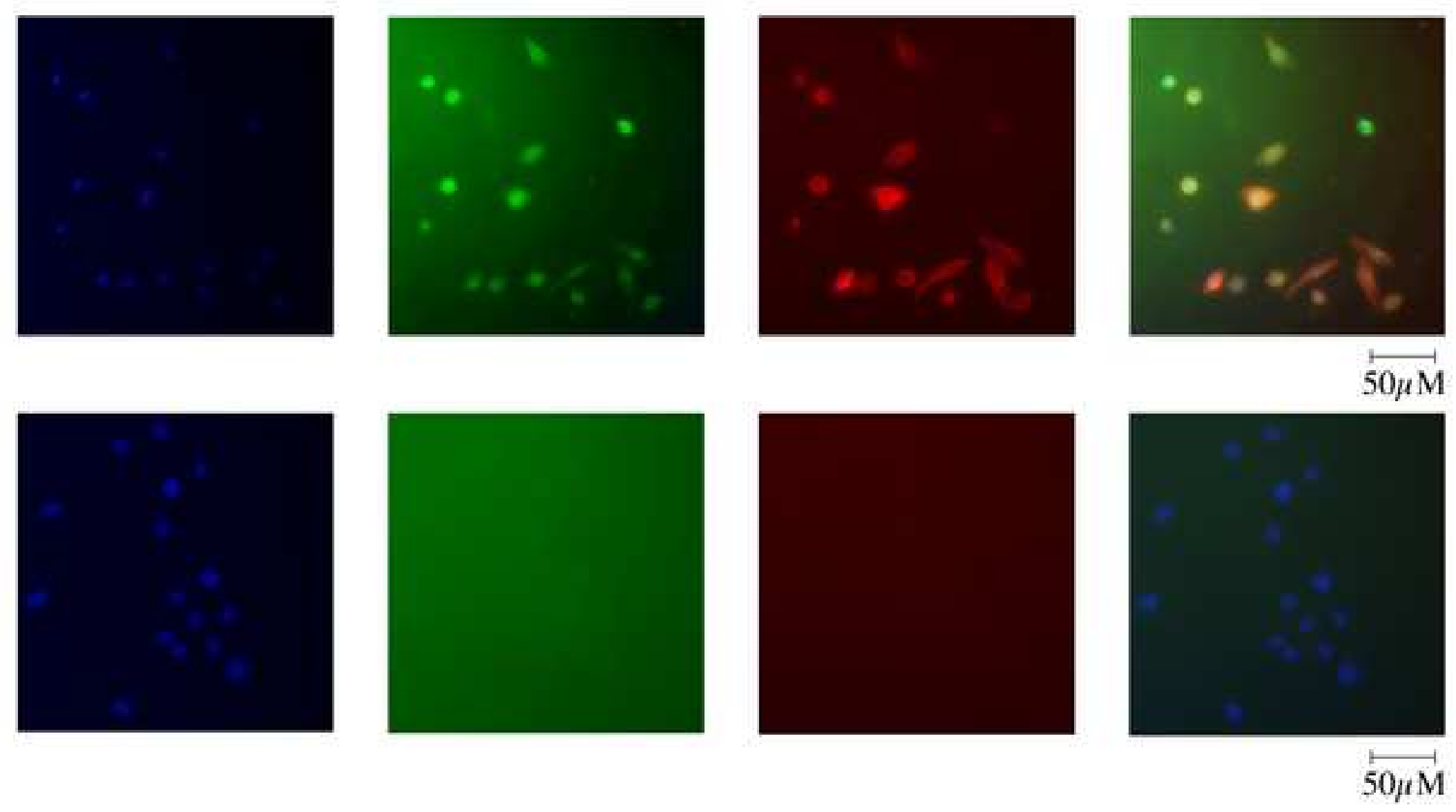

rage $1 y$ or 20 
Table 1

\begin{tabular}{|c|c|c|c|c|c|}
\hline Ligand & MC1R & MC2R & MC3R & MC4R & MC5R \\
\hline$\alpha-\mathrm{MSH}\left(\mathrm{EC}_{50} \mathrm{nM}\right)$ & 4 & $>1000$ & 1 & 2 & 20 \\
\hline $\mathrm{ACTH}_{(1-24)}\left(\mathrm{EC}_{50} \mathrm{nM}\right)$ & 11 & 1 & 7 & 4 & +3 \\
\hline$\gamma$-MSH $\left(\mathrm{EC}_{50} \mathrm{nM}\right)$ & 40 & $>1000$ & 6 & 300 & 600 \\
\hline Tissue distribution & $\begin{array}{l}\text { Melanocytes } \\
\text { Macrophages }\end{array}$ & $\begin{array}{c}\text { Adrenal } \\
\text { (Adipocytes in } \\
\text { rodents) }\end{array}$ & $\begin{array}{c}\text { Brain, Kidney, Gut, } \\
\text { Heart, Placenta, Adrenal }\end{array}$ & Brain, Spinal cord & $\begin{array}{l}\text { Adrenal, Brain, } \\
\text { Lung, Spleen. } \\
\text { Exocrine glands }\end{array}$ \\
\hline
\end{tabular}

